\title{
Caminibacter profundus sp. nov., a novel thermophile of Nautiliales ord. nov. within the class 'Epsilonproteobacteria', isolated from a deep-sea hydrothermal vent
}

Correspondence

M. L. Miroshnichenko

alfamirr@mail.ru

\author{
M. L. Miroshnichenko, ${ }^{1}$ S. L'Haridon, ${ }^{2}$ P. Schumann, ${ }^{3}$ S. Spring, ${ }^{3}$ \\ E. A. Bonch-Osmolovskaya, ${ }^{1}$ C. Jeanthon ${ }^{2}$ and E. Stackebrandt ${ }^{3}$ \\ ${ }^{1}$ Institute of Microbiology, Russian Academy of Sciences, Prospekt 60-letiya Oktyabrya 7/2, \\ Moscow 117811, Russia \\ ${ }^{2}$ UMR 6539, Centre National de la Recherche Scientifique and Université de Bretagne \\ Occidentale, Institut Universitaire Européen de la Mer, 29280 Plouzané, France \\ ${ }^{3} \mathrm{DSMZ}$ - German Collection of Microorganisms and Cell Cultures, Mascheroder Weg 1b, \\ 38124 Braunschweig, Germany
}

\begin{abstract}
A novel moderately thermophilic, microaerobic to anaerobic, chemolithoautotrophic bacterium, designated strain $\mathrm{CR}^{\top}$, was isolated from a deep-sea hydrothermal vent site at $36^{\circ} \mathrm{N}$ on the Mid-Atlantic Ridge. Cells were Gram-negative, non-motile rods. The organism grew at $45-65^{\circ} \mathrm{C}$ and $\mathrm{pH} 6 \cdot 5-7 \cdot 4$, with optimum growth at $55^{\circ} \mathrm{C}$ and $\mathrm{pH} 6 \cdot 9-7 \cdot 1$. The $\mathrm{NaCl}$ range for growth was 5-50 $\mathrm{gl}^{-1}$ (optimum $30 \mathrm{~g} \mathrm{I}^{-1}$ ). Strain $\mathrm{CR}^{\top}$ was an obligate chemolithoautotroph, growing with $\mathrm{H}_{2}$ as energy source, sulfur, nitrate or oxygen as electron acceptors and $\mathrm{CO}_{2}$ as carbon source. Hydrogen sulfide and ammonium were the respective products of sulfur and nitrate reduction. The $\mathrm{G}+\mathrm{C}$ content of the genomic DNA was $32 \cdot 1 \mathrm{~mol} \%$. Based on $16 \mathrm{~S}$ rRNA gene sequence analysis, this organism was most closely related to Caminibacter hydrogeniphilus ( $94.9 \%$ similarity). On the basis of phenotypic and phylogenetic data, it is proposed that the isolate represents a novel species, Caminibacter profundus sp. nov. The type strain is $\mathrm{CR}^{\top}$ (=DSM $15016^{\top}=$ JCM $11957^{\top}$ ). The phylogenetic data also correlate well with the significant phenotypic differences between the lineage encompassing the genera Nautilia and Caminibacter and other members of the class 'Epsilonproteobacteria'. The lineage encompassing the genera Nautilia and Caminibacter is therefore proposed as a new order, Nautiliales ord. nov., represented by a single family, Nautiliaceae fam. nov.
\end{abstract}

The class 'Epsilonproteobacteria' represents a recently recognized line of descent within the Proteobacteria that encompass two families within the single order 'Campylobacterales' (Garrity \& Holt, 2001). The family Campylobacteraceae contains the genera Campylobacter, Arcobacter, Sulfurospirillum and Thiovulum, whereas the family 'Helicobacteraceae' is formed by the genera Helicobacter and Wolinella. These bacteria are mesophiles adapted to environments that are low in oxygen. Most of them are oxidase-positive microaerophiles, but numerous members also grow in the absence of oxygen (Vandamme et al., 1991). Among them, Sulfurospirillum halorespirans and Sulfurospirillum multivorans have been described recently as obligate anaerobes (Luijten

Published online ahead of print on 20 June 2003 as DOI 10.1099/ ijs.0.02753-0.

The GenBank accession number for the $16 \mathrm{~S}$ rDNA sequence of Caminibacter profundus strain $\mathrm{CR}^{\top}$ is AJ535664. et al., 2003). All the above-mentioned genera, except for Thiovulum and Sulfurospirillum, which thrive in aquatic habitats, have been found associated with animals.

Assessment of microbial diversity using molecular phylogenetic approaches has revealed that members of the 'Epsilonproteobacteria' dominate various deep-sea hydrothermal habitats such as microbial mats of Loihi Seamount (Moyer et al., 1995), surfaces of invertebrates (Haddad et al., 1995; Polz \& Cavanaugh, 1995; Cary et al., 1997) and sulfides from the Mid-Atlantic Ridge (Reysenbach et al., 2000; Corre et al., 2001) and southern East Pacific Rise (Longnecker \& Reysenbach, 2001). Recently, thermophilic representatives of the 'Epsilonproteobacteria' have been isolated from tube fragments of Alvinella pompejana, an annelid polychaete endemic to chimney walls of the East Pacific Rise hydrothermal vents. Both Nautilia lithotrophica and Caminibacter hydrogeniphilus are strictly anaerobic hydrogen-oxidizers 
able to grow chemolithoautotrophically with sulfur as electron acceptor (Miroshnichenko et al., 2002; Alain et al., 2002). Other organisms that are phylogenetically closely related and phenotypically similar to these species have been partially characterized by Campbell et al. (2001). All these thermophilic isolates, along with a number of environmental sequences retrieved from hydrothermal systems, form a deep monophyletic unit within the 'Epsilonproteobacteria'. Very recently, many novel phylogenetically diverse representatives of the 'Epsilonproteobacteria' have been isolated from the hydrothermal fields of the Okinawa Trough and Central Indian Ridge and partially described (Takai et al., 2003). Here, a second species in the genus Caminibacter, Caminibacter profundus sp. nov., isolated from a hydrothermal vent of the Mid-Atlantic Ridge, is described.

Strain $\mathrm{CR}^{\mathrm{T}}$ was isolated from material collected using a vent cap at the Rainbow hydrothermal vent field $\left(36^{\circ} 16^{\prime} \mathrm{N}\right.$; $33^{\circ} 54^{\prime} \mathrm{W} ; 2400 \mathrm{~m}$ depth) on the Mid-Atlantic Ridge during the Iris cruise in May 2001. An in situ growth chamber or vent cap (Reysenbach et al., 2000), designed to concentrate the micro-organisms discharged by hydrothermal emissions, was deployed using the hydraulic arm of the remotely operated vehicle Victor. After incubation in situ for 2 days, the vent cap was closed by the hydraulic arm of the remotely operated vehicle before transportation to the surface. Once on board, the vent cap content was immediately transferred to $50 \mathrm{ml}$ glass vials and flooded with a sterile solution of $3 \%(w / v)$ sea salts (Sigma). The vials were then closed tightly with butyl rubber stoppers (Bellco), pressurized with $\mathrm{N}_{2}(100 \mathrm{kPa})$, reduced with sodium sulfide and stored at $4{ }^{\circ} \mathrm{C}$ until further processing in the laboratory.

For enrichment, the following basal medium $(\mathrm{BM})$ was used ( $\mathrm{g} \mathrm{l}^{-1}$, unless otherwise stated): $\mathrm{NH}_{4} \mathrm{Cl}, 0 \cdot 33 ; \mathrm{KCl}, 0 \cdot 33$; $\mathrm{KH}_{2} \mathrm{PO}_{4}, 0.33 ; \mathrm{CaCl}_{2} .2 \mathrm{H}_{2} \mathrm{O}, 0.33 ; \mathrm{MgCl}_{2} .6 \mathrm{H}_{2} \mathrm{O}, 0.33 ; \mathrm{NaCl}$, $25 \cdot 0$; yeast extract, $0 \cdot 1$; trace elements (Balch et al., 1979), $10 \mathrm{ml} \mathrm{l}^{-1}$; vitamins (Wolin et al., 1963), $10 \mathrm{ml} \mathrm{l}^{-1}$. The medium was prepared anaerobically and dispensed into Bellco tubes; the headspace ( $25 \mathrm{ml}$ ) was filled with $\mathrm{H}_{2} / \mathrm{CO}_{2}$, $(80: 20,200 \mathrm{kPa})$. No reducing agents were added to the medium. Elemental sulfur was added to a final concentration of $10 \mathrm{~g} \mathrm{l}^{-1}$. The $\mathrm{pH}$ of the medium was adjusted with $2 \cdot 5 \mathrm{M} \mathrm{H}_{2} \mathrm{SO}_{4}$ to $6 \cdot 8-7 \cdot 0$. When substrates other than molecular hydrogen were tested, the headspace was filled with $\mathrm{N}_{2} / \mathrm{CO}_{2}(8: 2, \mathrm{v} / \mathrm{v}$, atmospheric pressure). A pure culture was obtained on the same basal medium without yeast extract using a serial tenfold dilution technique. Morphology of the novel isolate was examined using an Olympus BX-60 microscope. The ultrastructure of whole cells and thin sections was studied as described elsewhere (BonchOsmolovskaya et al., 1990). For physiological studies, the isolate was grown on BM medium containing MOPS $(10 \mathrm{mM})$ as a buffer. The $\mathrm{pH}$ of the medium was adjusted to $7 \cdot 0$ with $5 \mathrm{M} \mathrm{NaOH}$ before autoclaving. Potential growth substrates and electron acceptors were added at concentrations of 0.3 and $0.2 \%(\mathrm{w} / \mathrm{v})$, respectively. The ability of the isolate to grow microaerobically and/or aerobically was tested on BM medium, with oxygen added to the $\mathrm{H}_{2} / \mathrm{CO}_{2}$ mixture $(80: 20, \mathrm{v} / \mathrm{v}, 200 \mathrm{kPa})$; the final concentration of oxygen varied from $0 \cdot 25$ to $20 \%$. Carbon source utilization was determined using substrates at a concentration of $0.05 \%$; in this case, the headspace was filled with $100 \% \mathrm{H}_{2}$ (atmospheric pressure). Inoculated tubes were incubated at $55^{\circ} \mathrm{C}$. The cell density was determined by direct cell counting using a light microscope. Gaseous and liquid fermentation products, as well as the products of nitrate reduction, were detected as described previously (Miroshnichenko et al., 1994, 2003). Hydrogen sulfide was measured by a colorimetric method (Trüper \& Schlegel, 1964). The sensitivity of strain $\mathrm{CR}^{\mathrm{T}}$ to rifampicin, chloramphenicol, vancomycin, penicillin, streptomycin and tetracycline (Sigma) was tested at a concentration of $100 \mu \mathrm{g} \mathrm{ml}^{-1}$. Determination of the DNA G $+C$ content was performed as described elsewhere (Miroshnichenko et al., 2003). DNA extraction, PCR amplification of the 16S rRNA gene and determination of the sequence followed described methods (Rainey et al., 1996). The 16S rRNA sequences were aligned with published sequences of the DSMZ database using the ae2 editor (Maidak et al., 1999) and sequences retrieved from EMBL. Evolutionary distances were calculated by the method of Jukes \& Cantor (1969). Distance analysis dendrograms were reconstructed by the neighbour-joining algorithm. Bootstrap analysis was used to evaluate the tree topology by performing 500 resamplings (Felsenstein, 1988).

Enrichment was performed in Bellco tubes filled with $5 \mathrm{ml}$ $\mathrm{BM}$ medium. $\mathrm{A} \mathrm{H}_{2} / \mathrm{CO}_{2}$ mixture $(80: 20,200 \mathrm{kPa})$ served as the energy and carbon source, and elemental sulfur was the electron acceptor. After inoculation of BM medium with $0.5 \mathrm{ml}$ material recovered from the vent cap content and inner surfaces and incubation of the tubes for 3 days at $55^{\circ} \mathrm{C}$ without shaking, growth of non-motile rods was observed, accompanied by the formation of hydrogen sulfide. Transfer of the enrichment culture into BM medium without yeast extract did not affect its growth. A pure culture, $\mathrm{CR}^{\mathrm{T}}$, was isolated by serial dilutions in liquid mineral medium. Purity of the culture was checked by the absence of growth in a non-selective glucose- and peptone-containing medium (each at $3 \mathrm{~g} \mathrm{l}^{-1}$ ).

Cells of strain $\mathrm{CR}^{\mathrm{T}}$ were rod-shaped (approximately $1 \cdot 2-$ $1.5 \times 0.5 \mu \mathrm{m})$ and motile in the exponential phase of growth. One polar flagellum was present on negatively stained whole-cell preparations (Fig. 1a). Formation of spores was not observed. Thin sectioning revealed the Gram-negative structure of the cell wall (Fig. 1b).

Strain $\mathrm{CR}^{\mathrm{T}}$ grew anaerobically with molecular hydrogen as the energy source and elemental sulfur or nitrate as the electron acceptors. The only product detected during growth with $\mathrm{S}^{0}$ was $\mathrm{H}_{2} \mathrm{~S}$. Ammonium was the only product of nitrate reduction. Strain $\mathrm{CR}^{\mathrm{T}}$ was also able to grow microaerobically at low oxygen concentrations (up to $2 \%$, optimal at $0 \cdot 5 \%$ ). With hydrogen, $\mathrm{S}^{0}$ and $\mathrm{CO}_{2}$ as electron donor, electron acceptor and carbon source, respectively, the isolate grew at $45-65^{\circ} \mathrm{C}$, with optimum growth around 

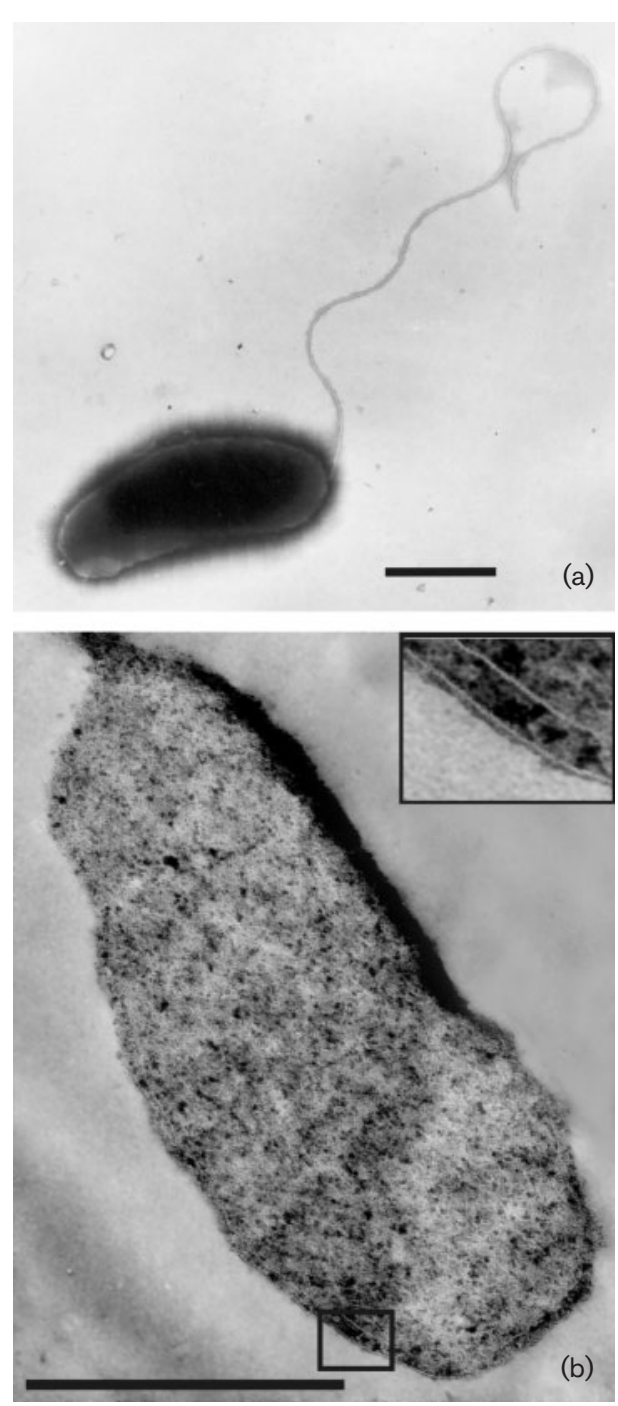

Fig. 1. Electron micrographs of strain $\mathrm{CR}^{\top}$. Negatively stained cell showing polar flagellum (a) and ultrathin section of the cell (b). Bars, $0.5 \mu \mathrm{m}$.

$55{ }^{\circ} \mathrm{C}$. The $\mathrm{pH}$ range for growth was $6 \cdot 5-7 \cdot 4$ (optimum at pH 6.9-7·0). Optimal $\mathrm{NaCl}$ concentration for growth was $30 \mathrm{~g} \mathrm{l}^{-1}$; no growth was observed in media containing less than 5 or more than $50 \mathrm{~g} \mathrm{NaCl} l^{-1}$. Under optimal conditions, the doubling time was about $40 \mathrm{~min}$ and the cell yield reached $7 \times 10^{8}$ cells $\mathrm{ml}^{-1}$. A slightly higher cell yield (about $1.5 \times 10^{9}$ cells ml $^{-1}$ ) was obtained under $0.5 \%$ oxygen. Acetate, formate, butyrate, propionate, malate, succinate, methanol, ethanol, pyruvate, lactate, fumarate, methylamine, glucose, sucrose, starch, peptone and yeast extract did not support growth. Strain $\mathrm{CR}^{\mathrm{T}}$ did not grow when sulfate, sulfite or thiosulfate were provided as alternative electron acceptors. To examine possible carbon sources other than $\mathrm{CO}_{2}$, acetate, pyruvate, formate, methylamine, methanol and malate were tested; none of them supported growth. Strain $\mathrm{CR}^{\mathrm{T}}$ was sensitive to rifampicin, vancomycin, penicillin and streptomycin (all at
$100 \mu \mathrm{g} \mathrm{ml}^{-1}$ ). It grew in the presence of chloramphenicol and tetracycline (both at $100 \mu \mathrm{g} \mathrm{ml}^{-1}$ ). The $\mathrm{G}+\mathrm{C}$ content of the DNA of isolate $\mathrm{CR}^{\mathrm{T}}$ was $32 \cdot 1 \mathrm{~mol} \%$.

Comparison of the 16S rRNA gene sequence (1414 bases) with those of members of the domain Bacteria indicated that strain $\mathrm{CR}^{\mathrm{T}}$ belonged to the class 'Epsilonproteobacteria' and was moderately related to C. hydrogeniphilus (94.9\% similarity) and $N$. lithotrophica ( $91 \cdot 2 \%$ similarity), both of which were isolated from $13^{\circ} \mathrm{N}$ on the East Pacific Rise. Strain $\mathrm{CR}^{\mathrm{T}}$ showed higher sequence similarity $(92 \cdot 3-96 \cdot 1 \%)$ to a group of clone sequences retrieved from material from deep-sea hydrothermal vents on the Mid-Atlantic Ridge (VC2.1Bac7, VC2.1Bac17, VC2.1Bac8, VC2.1Bac30; Reysenbach et al., 2000). Slightly lower similarities $(91 \cdot 4-93 \cdot 7 \%)$ were found to clone sequences retrieved from South-East Pacific vents (S17sBac14, S17sBac3, S17sBac5; Longnecker \& Reysenbach, 2001) and to isolate AM1115 (Alain et al., 2002).

The phylogenetic relatedness of strain $\mathrm{CR}^{\mathrm{T}}$ to C. hydrogeniphilus is consistent with shared physiological characteristics and the DNA G + C content (Table 1). Both strains are moderately thermophilic chemolithoautotrophs, growing with hydrogen as electron donor and elemental sulfur or nitrate as electron acceptors. However, C. hydrogeniphilus has been described as a strictly anaerobic micro-organism, whereas strain $\mathrm{CR}^{\mathrm{T}}$ is able to grow anaerobically and microaerobically at an oxygen concentration of up to $2 \%$. The isolate has a narrow $\mathrm{pH}$ growth optimum of $6 \cdot 9-7 \cdot 1$, whereas C. hydrogeniphilus grows optimally at pH 5.5-6.5. In contrast to C. hydrogeniphilus, which is capable of poor heterotrophic growth on complex organic substrates, strain $\mathrm{CR}^{\mathrm{T}}$ is a strictly lithotrophic micro-organism. Thus, on the basis of phylogenetic, morphological and physiological features, it is proposed that $\mathrm{CR}^{\mathrm{T}}\left(=\mathrm{DSM} 15016^{\mathrm{T}}=\right.$ JCM $11957^{\mathrm{T}}$ ) is the type strain of a novel species of Caminibacter, for which the name Caminibacter profundus sp. nov. is proposed.

The class 'Epsilonproteobacteria' (Garrity \& Holt, 2001) is represented by a single tentative order, 'Campylobacterales'. The order presently contains the family Campylobacteraceae (Vandamme \& De Ley, 1991) and the as-yet tentative family 'Helicobacteraceae' (Garrity \& Holt, 2001). Levels of $16 \mathrm{~S}$ rRNA gene sequence similarity between the lineage encompassing Nautilia and Caminibacter and the 'Campylobacterales' are about $83 \%$ (Fig. 2). Phenotypic and genomic features also clearly distinguish the two phylogenetic lineages (Table 1). It is therefore proposed that members of the genera Nautilia and Caminibacter form a new order, Nautiliales ord. nov., represented by the single family Nautiliaceae fam. nov.

\section{Description of Nautiliales ord. nov. Miroshnichenko et al.}

Nautiliales (Nau.ti'li.a.les. N.L. fem. n. Nautilia the type genus of the order; N.L. -ales ending denoting an order; N.L. fem. pl. n. Nautiliales the order of Nautilia). 
Table 1. Differentiating characteristics of the families Nautiliaceae fam. nov., Campylobacteraceae and 'Helicobacteraceae'

Data for Nautiliaceae were taken from Alain et al. (2002), Miroshnichenko et al. (2002) and this study. The family Campylobacteraceae contains the genera Campylobacter, Arcobacter, Sulfurospirillum and Thiovulum (data from Vandamme \& De Ley, 1991; Vandamme et al., 1991; La Riviere \& Schmidt, 1992; Schumacher et al., 1992; Luijten et al., 2003). The tentative family 'Helicobacteraceae' contains the genera Helicobacter and Wolinella (data from Tanner et al., 1981; Vandamme et al., 1991).

\begin{tabular}{|c|c|c|c|}
\hline Characteristic & Nautiliaceae & Campylobacteraceae & 'Helicobacteraceae' \\
\hline Morphology & Rods & Helical, curved, S-shaped, spiral rods or ovoid & Helical, curved or straight rods \\
\hline $\mathrm{O}_{2}$ requirement & $\begin{array}{l}\text { Obligate anaerobic } \\
\text { or microaerobic }\end{array}$ & Microaerobic, some strains aerobic or anaerobic & Anaerobic or microaerobic \\
\hline $\mathrm{H}_{2}$ oxidation & + & - & + or - \\
\hline Sulfur reduction & + & $-*$ & - \\
\hline Metabolism & $\begin{array}{l}\text { Chemolithotrophic } \\
\text { or mixotrophic }\end{array}$ & $\begin{array}{l}\text { Chemo-organotrophic; Sulfospirillum, mixotrophic; } \\
\text { Thiovolum, chemolithotrophic }\end{array}$ & $\begin{array}{l}\text { Chemo-organotrophic or } \\
\text { mixotrophic }\end{array}$ \\
\hline Thermophily & + & - & - \\
\hline $\mathrm{G}+\mathrm{C}$ content $(\mathrm{mol} \%)$ & $29-35$ & $28-49$ & $35-46$ \\
\hline
\end{tabular}

*Sulfur is reduced by Sulfurospirillum species.

Order of the 'Epsilonproteobacteria' separate and distinct from the 'Campylobacterales'. Segregation of these organisms into a new order is justified by (i) their distinct phylogenetic position and (ii) their thermophilic way of life. Marine thermophilic rod-shaped bacteria, mean cell size of $0.5 \times 1.3 \mu \mathrm{m}$, non-spore-forming. Gram-negative. Obligately anaerobic or microaerobic. For anaerobic growth,

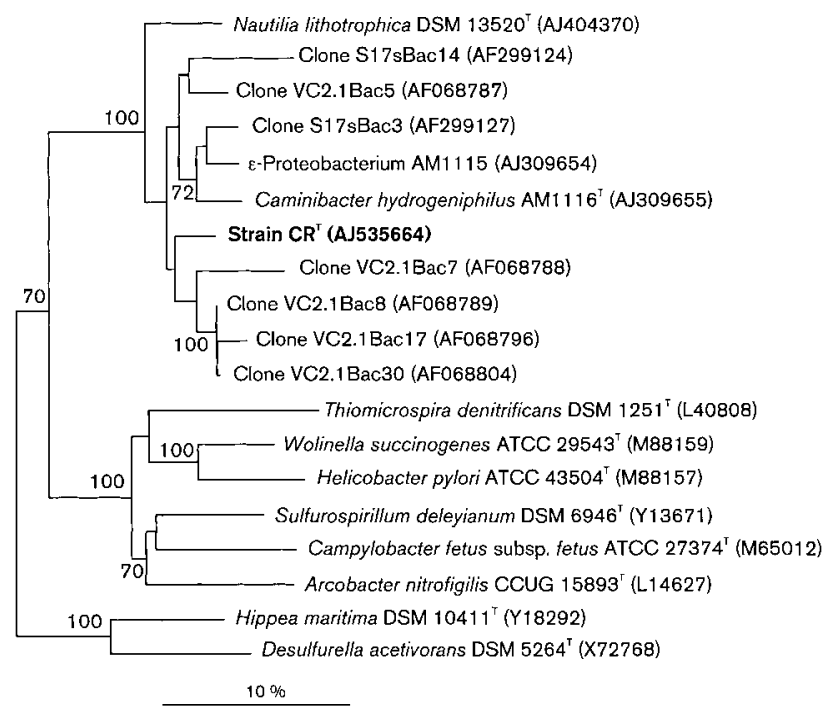

Fig. 2. Neighbour-joining dendrogram based on $16 \mathrm{~S}$ rDNA sequences showing the position of strain $\mathrm{CR}^{\top}$ in relation to its phylogenetic neighbours, members of the genera Caminibacter and Nautilia, 'Epsilonproteobacteria' and as-yet uncultured bacteria from vents of the Pacific and Atlantic. Percentages of 500 bootstrap resamplings that support branching points above $70 \%$ confidence are indicated. Bar, $10 \mathrm{nt}$ substitutions per 100 sequence positions. The tree was rooted with $16 \mathrm{~S}$ rDNA sequences of members of the class 'Gammaproteobacteria'. sulfur or nitrate are used as electron acceptors. Chemolithoautotrophs; mixotrophy occurs. Positive for $\mathrm{H}_{2}$ oxidation. DNA G $+\mathrm{C}$ content of $29-35 \mathrm{~mol} \%$. Type genus: Nautilia Miroshnichenko et al. 2002.

\section{Description of Nautiliaceae fam. nov. Miroshnichenko et al.}

Nautiliaceae (Nau.ti'li.a.ce.ae. N.L. fem. n. Nautilia the type genus of the family; N.L. -aceae ending denoting a family; N.L. fem. pl. n. Nautiliaceae the family of Nautilia).

Description is the same as that for the order. Type genus: Nautilia Miroshnichenko et al. 2002.

\section{Description of Caminibacter profundus sp. nov.}

Caminibacter profundus (pro.fun'dus. L. masc. adj. profundus of the depths of the ocean).

Cells are motile, rod-shaped $(1 \cdot 2-1 \cdot 5 \times 0 \cdot 5 \mu \mathrm{m})$ with single polar flagellum. Gram-negative cell wall structure. Anaerobic to microaerobic. Spores absent. Moderate thermophile, growing at $45-65^{\circ} \mathrm{C}$ (optimum $55^{\circ} \mathrm{C}$ ). Neutrophile, growing at $\mathrm{pH} 6 \cdot 5-7 \cdot 4$ (optimum $\mathrm{pH} 6 \cdot 9-7 \cdot 1$ ). Grows in 5-50 g $\mathrm{NaCl} \mathrm{l}^{-1}$ (optimum around $30 \mathrm{~g} \mathrm{NaCl}^{-1}$ ). Utilizes $\mathrm{H}_{2}$ as energy source, elemental sulfur, nitrate or oxygen as electron acceptors and $\mathrm{CO}_{2}$ as carbon source. Nitrate and sulfur are respectively reduced to ammonium and hydrogen sulfide in the course of growth. Growth is not supported by acetate, formate, butyrate, propionate, malate, succinate, methanol, ethanol, pyruvate, lactate, fumarate, methylamine, glucose, sucrose, starch, peptone or yeast extract. Acetate, pyruvate, formate, methylamine, methanol and malate cannot replace $\mathrm{CO}_{2}$ as carbon source. Sulfate, sulfite and thiosulfate are not utilized as electron acceptors. Grows in the presence of chloramphenicol and tetracycline (both at $100 \mu \mathrm{g} \mathrm{ml}^{-1}$ ). DNA G $+\mathrm{C}$ content of the type strain is $32 \cdot 1 \mathrm{~mol} \%$. 
The type strain, $\mathrm{CR}^{\mathrm{T}}\left(=\mathrm{DSM} 15016^{\mathrm{T}}=\mathrm{JCM} 11957^{\mathrm{T}}\right)$, was isolated from the content of a vent cap deployed in the Mid-Atlantic Ridge $\left(23^{\circ} \mathrm{N}\right)$.

\section{Acknowledgements}

We thank Yves Fouquet (chief scientist) for inviting us to participate in the Iris cruise (2001) and the crews of R/V L'Atalante and the pilots of the ROV Victor. This work was supported by a CNRS/Rhône-Poulenc grant, a PRIR grant from the Conseil Régional de Bretagne, INTAS grant no. 99-1250 and the 'Biodiversity' programme of the Russian Ministry of Industry, Science and Technology. M. L. M. was supported by the Ministère de l'Education Nationale during her stay in France.

\section{References}

Alain, K., Querellou, J., Lesongeur, F., Pignet, P., Crassous, P., Raguénès, G., Cueff, V. \& Cambon-Bonavita, M.-A. (2002). Caminibacter hydrogeniphilus gen. nov., sp. nov., a novel thermophilic, hydrogen-oxidizing bacterium isolated from an East Pacific Rise hydrothermal vent. Int J Syst Evol Microbiol 52, 1317-1323.

Balch, W. E., Fox, G. E., Magrum, L. J., Woese, C. R. \& Wolfe, R. S. (1979). Methanogens: re-evaluation of a unique biological group. Microbiol Rev 43, 260-296.

Bonch-Osmolovskaya, E. A., Sokolova, T. G., Kostrikina, N. A. \& Zavarzin, G. A. (1990). Desulfurella acetivorans gen. nov. and sp. nov. - a new thermophilic sulfur-reducing eubacterium. Arch Microbiol 153, 151-155.

Campbell, B. J., Jeanthon, C., Kostka, J. E., Luther, G. W., III \& Cary, S. C. (2001). Growth and phylogenetic properties of novel bacteria belonging to the epsilon subdivision of the Proteobacteria enriched from Alvinella pompejana and deep-sea hydrothermal vents. Appl Environ Microbiol 67, 4566-4572.

Cary, S. C., Cottrell, M. T., Stein, J. L., Camacho, F. \& Desbruyères, D. (1997). Molecular identification and localization of filamentous symbiotic bacteria associated with the hydrothermal vent annelid Alvinella pompejana. Appl Environ Microbiol 63, 1124-1130.

Corre, E., Reysenbach, A.-L. \& Prieur, D. (2001). $\varepsilon$-Proteobacterial diversity from a deep-sea hydrothermal vent on the Mid-Atlantic Ridge. FEMS Microbiol Lett 205, 329-335.

Felsenstein, J. (1988). Phylogenies from molecular sequences: inference and reliability. Annu Rev Genet 22, 521-565.

Garrity, G. M. \& Holt, J. G. (2001). The road map to the Manual. In Bergey's Manual of Systematic Bacteriology, 2nd edn, vol. 1, pp. 119-166. Edited by D. R. Boone \& R. W. Castenholz. New York: Springer.

Haddad, A., Camacho, F., Durand, P. \& Cary, S. C. (1995). Phylogenetic characterization of the epibiotic bacteria associated with the hydrothermal vent polychaete Alvinella pompejana. Appl Environ Microbiol 61, 1679-1687.

Jukes, T. H. \& Cantor, C. R. (1969). Evolution of protein molecules. In Mammalian Protein Metabolism, vol. 3, pp. 21-132. Edited by H. N. Munro. New York: Academic Press.

La Riviere, J. W. M. \& Schmidt, K. (1992). Morphologically conspicuous sulfur-oxidizing eubacteria. In The Prokaryotes, 2nd edn, pp. 3934-3947. Edited by A. Balows, H. G. Trüper, M. Dworkin, W. Harder \& K.-H. Schleifer. New York: Springer.

Longnecker, K. \& Reysenbach, A. (2001). Expansion of geographic distribution of a novel lineage of $\varepsilon$-Proteobacteria to a hydrothermal vent site on the southern East Pacific Rise. FEMS Microbiol Ecol 35, 287-293.
Luijten, M. L. G. C., de Weert, J., Smidt, H., Boschker, H. T. S., de Vos, W. M., Schraa, G. \& Stams, A. J. M. (2003). Description of Sulfurospirillum halorespirans sp. nov., an anaerobic tetrachloroethene-respiring bacterium, and transfer of Dehalospirillum multivorans to the genus Sulfurospirillum as Sulfurospirillum multivorans comb. nov. Int J Syst Evol Microbiol 53, 787-793.

Maidak, B. L., Cole, J. R., Parker, C. T., Jr \& 11 other authors (1999). A new version of the RDP (Ribosomal Database Project). Nucleic Acids Res 27, 171-173.

Miroshnichenko, M. L., Gongadze, G. M., Lysenko, A. M. \& Bonch-Osmolovskaya, E. A. (1994). Desulfurella multipotens sp. nov., a new sulfur-respiring thermophilic eubacterium from Raoul Island (Kermadec archipelago). Arch Microbiol 161, 88-93.

Miroshnichenko, M. L., Kostrikina, N. A., L'Haridon, S., Jeanthon, C., Hippe, H., Stackebrandt, E. \& Bonch-Osmolovskaya, E. A. (2002). Nautilia lithotrophica gen. nov., sp. nov., a thermophilic sulfurreducing $\varepsilon$-proteobacterium isolated from a deep-sea hydrothermal vent. Int J Syst Evol Microbiol 52, 1299-1304.

Miroshnichenko, M. L., Kostrikina, N. A., Chernyh, N. A., Pimenov, N. V., Tourova, T. P., Antipov, A. N., Spring, S., Stackebrandt, E. \& Bonch-Osmolovskaya, E. A. (2003). Caldithrix abyssi gen. nov., sp. nov., a nitrate-reducing, thermophilic, anaerobic bacterium isolated from a Mid-Atlantic Ridge hydrothermal vent, represents a novel bacterial lineage. Int J Syst Evol Microbiol 53, 323-329.

Moyer, C. L., Dobb, F. C. \& Karl, D. M. (1995). Phylogenetic diversity of the bacterial community from a microbial mat at an active, hydrothermal vent system. Appl Environ Microbiol 61, 1555-1562.

Polz, M. F. \& Cavanaugh, C. M. (1995). Dominance of one bacterial phylotype at a Mid-Atlantic Ridge hydrothermal vent site. Proc Natl Acad Sci U S A 92, 7232-7236.

Rainey, F. A., Ward-Rainey, N., Kroppenstedt, R. M. \& Stackebrandt, E. (1996). The genus Nocardiopsis represents a phylogenetically coherent taxon and a distinct actinomycete lineage: proposal of Nocardiopsaceae fam. nov. Int J Syst Bacteriol 46, 1088-1092.

Reysenbach, A.-L., Longnecker, K. \& Kirshtein, J. (2000). Novel bacterial and archaeal lineages from an in situ growth chamber deployed at a Mid-Atlantic Ridge hydrothermal vent. Appl Environ Microbiol 66, 3798-3806.

Schumacher, W., Kroneck, P. M. H. \& Pfennig, N. (1992). Comparative systematic study on 'Spirillum' 5175, Campylobacter and Wolinella species. Arch Microbiol 158, 287-293.

Takai, K., Inagaki, F., Nakagawa, S., Hirayama, H., Nunoura, T., Sako, Y., Nealson, K. H. \& Horikoshi, K. (2003). Isolation and phylogenetic diversity of members of previously uncultivated $\varepsilon$-Proteobacteria in deep-sea hydrothermal fields. FEMS Microbiol Lett 218, 167-174.

Tanner, A. C. R., Badger, S. M., Lai, C.-H., Listgarten, M. A., Visconti, R. A. \& Socransky, S. S. (1981). Wolinella gen. nov., Wolinella succinogenes (Vibrio succinogenes Wolin et al.) comb. nov., and description of Bacteroides gracilis sp. nov., Wolinella recta sp. nov., Campylobacter concisus sp. nov., and Eikenella corrodens from humans with periodontal disease. Int J Syst Bacteriol 31, 432-445.

Trüper, H. G. \& Schlegel, H. G. (1964). Sulfur metabolism in Thiorhodaceae. I. Quantitative measurements on growing cells of Chromatium okenii. J Microbiol Serol 30, 225-232.

Vandamme, P. \& De Ley, J. (1991). Proposal for a new family, Campylobacteraceae. Int J Syst Bacteriol 41, 451-455.

Vandamme, P., Falsen, E., Rossau, R., Hoste, B., Segers, P., Tytgat, R. \& De Ley, J. (1991). Revision of Campylobacter, Helicobacter, and Wolinella taxonomy: emendation of generic descriptions and proposal of Arcobacter gen. nov. Int J Syst Bacteriol 41, 88-103.

Wolin, E. A., Wolin, M. J. \& Wolfe, R. S. (1963). Formation of methane by bacterial extracts. J Biol Chem 238, 2882-2888. 